UDC 378.1:334.764.47

http://doi.org/10.21272/mmi.2019.2-17

JEL Classification: A23, 121, J24

Krzysztof Wodarski,

D.Sc., Associate Professor, Silesian University of Technology, Poland

Joanna Machnik-Slomka,

Ph.D., Assistant Professor, Silesian University of Technology, Poland

Jakub Semrau,

Silesian University of Technology, Poland

\title{
STUDENTS' COMPETENCIES FOR THE FUTURE AND INNOVATIVENESS - RESEARCH AMONG MANAGERIAL STAFF OF PUBLIC UNIVERSITIES OF TECHNOLOGY IN POLAND
}

Abstract. Socio-economic processes, development of technology and accompanying changes create a working environment with a high dynamic of change that requires constant learning and innovative orientation. This is related to the need to modify and increase knowledge and targeted competence development. In this regard, academic education plays an essential role. Therefore, the article discusses the issue of shaping key competencies of the future for technical students of universities in Poland from the perspective of academic education particularly in regard to aspects of innovation. Undertaking research in this area is an important and complex endeavour. The article also draws attention to contemporary social and economic processes which determine the demand for future competencies of university students. The purpose of the article is to identify the students' key competencies of the future which in the coming years will be significant and necessary for the development and identification of the most effective ways and methods of education developing and strengthening these competencies in particular in the innovation area. The empirical research was based on the interview method and the expert panel method. The respondents to the survey were the deans and pro-deans of the faculties of Polish public technical universities where the fields of study within the disciplines of economics and finance as well as management and quality sciences are conducted. The article presents the results of empirical research which indicate some discrepancies between the competencies and the demand of the labour market for the desired competencies of students in the opinion of the management staff of the surveyed universities. It was assumed that innovative competencies play an important role among competencies for the future identified by the respondents. The results show that the development of knowledge, skills and attitudes related primarily to cognitive, social and interpersonal competencies, as well as technical and digital competencies, competencies related to innovation, interdisciplinarity and multiculturalism are vital for the development of future competencies of graduates on the labour market. Research results can be useful to design more efficiently a learning process aimed at shaping the competencies of the future of students to prepare them to assume different roles in a changing and diverse context.

Keywords: competencies, innovation, innovation management, education, labour market.

Introduction. Very dynamic changes taking place in the environment mean that it is necessary to respond quickly to new conditions. In this process, the demand for competencies sought in the labour market changes. There is a need to develop new competencies, including innovative competencies, that would allow for better adaptation and functioning on the labour market. This should be taken into consideration in particular by decision-makers and managers of various organisations and universities. Education is the key to shaping and developing these competencies. Modern education process is considered in the context of the idea of lifelong learning. $n$ current times, this idea is characterised by an unparalleled acceleration of civilisation, social and technological development, therefore, it has acquired a new meaning (Kwiatkowski, 2018). Borowiec-Gabrys, Kilar, Rachwal (Borowiec-Gabrys et al., 2018) refer to the OECD report which indicates that as many as 65 percent of children starting education will work in professions that do not yet exist. This poses a huge challenge to the whole education system: how to prepare young people to play different roles in different and changing situations in the future? This dynamics of change and diversity inspire activity, dialogue and changes in established patterns of

Cite as: Wodarski, K., Machnik-Slomka, J., \& Semrau, J. (2019). Students' Competencies for the Future and Innovativeness - Research Among Managerial Staff of Public Universities of Technology in Poland. Marketing and Management of Innovations, 2, 198205. http://doi.org/10.21272/mmi.2019.2-17 
thinking and acting (Najder-Stefaniak, 2010). This means that the education obtained in a particular field in the academic education process needs to be updated and further improved. The high level of complexity of occupational problems also requires combining the acquired education with the education assigned so far to other, not always related fields of study and scientific disciplines (Kwiatkowski, 2018). The article is a reflection on the directions of development and challenges faced by university management staff looking for more effective ways of teaching and learning process adapting to the labour market. Thinking about the competencies of the future, considered in the perspective of a dozen or so years, has a deep educational sense. On the one hand, it allows universities to prepare and properly design their education processes. On the other hand, it highlights the need to prepare students to assume different roles in the context of diverse and changing situations in professional and social life.

The article therefore focuses on seeking answers to the following questions:

- What competencies of the future will be of key importance on the labour market (increasing the chances of coping with various professional and life situations) from the perspective of universities in the area:

- knowledge - what kind of knowledge is needed for students to learn?

- skills - what skills should be developed and how should they be developed when carrying out various types of tasks?

- attitudes - how to stimulate and motivate students to earn achievements, ignite desired behaviours and motives for action, taking on specific social roles, management styles and value systems?

- How to develop and strengthen the shaping of necessary competencies of the future on the labour market?

These promisses and the literature analysis showed the need to conduct research on the key competencies of the future among the management of technical universities in Poland.

The aim of the paper is to identify the key competencies of the future of students, which in the coming years will be important and necessary for the development and identification of the most effective ways and methods of education developing and strengthening these competencies in particular in the innovation area. Against this background, the competencies held by graduates were also assessed in comparison to the assessed demand for these competencies in the labour market. The results obtained on the basis of research conducted among the management staff of technical universities in Poland indicate certain discrepancies between the competencies of students and the labour market demand for the desired competencies. The surveyed respondents also indicated the competencies which in their opinion will be of key importance in the future on the labour market and the most effective ways of teaching these competencies.

Literature Review. Changing environmental conditions encourage reflection on the necessary competencies of university students in the labour market, in particular in the context of the key competencies of the future, considered in the perspective of several years. They are particularly affected by the following dynamic changes and directions of development (Kwiatkowski, 2018). These are:

- directions of world economy development resulting from the fourth industrial revolution (related to alternative energy sources, use of IT methods and techniques, that is, artificial intelligence automation and robotization of production and services);

- demographic change (ageing population);

- changes in the social structure related to the level of education and increasing economic stratification;

- the concept of immigration policy;

- improving quality of life (healthy food, health and image, sport and recreation).

Many authors point to the need to conduct research in this area (e.g. Jerman et al., 2018; 
Stachowicz-Stanusch and Aleksander, 2018; Kuzior A., 2014). The concept of competence is widespread and used in many scientific disciplines (Mulder et al., 2009). There is therefore no single definition. The term 'competence' was introduced into the literature of the subject in the 80 's of the 20th century by R. Boyatzis. According to the author, competence is a potential existing in a human being, leading to such behaviour which contributes to satisfying the requirements of a given job position within the parameters of the organisation's environment which in turn gives a desired result (Boyatzis, 1982). Roberts defines competence as a set of personality traits, knowledge, experience, skills, and values that we need to successfully perform a job (Roberts, 1997). Spencer and Spencer define competencies of the individual as the visible and hidden characteristics of the individual, which are reflected in the level of success in specific tasks (Spencer and Spencer, 1993). The very concept of competence comes from the Latin word 'competentia' and means 'compliance, adequacy, scope of powers and authorisations' (Markowski and Pawelec, 2003). Just as there is no single definition of competence, there is no single classification in the literature (Jerman et al. 2018). There are many classifications of competencies. Competencies can be defined in terms of cognitive factors (e.g. different types of knowledge), intellectual and perceptual motor skills (e.g. dexterity), affective factors (e.g. attitudes, values, motivation etc.), personality traits (e.g. self-confidence) and social skills (e.g. communicative and cooperative skills) (Ellstrom and Kock, 2009). Hecklau et al. classify competencies into four categories, namely technical, methodological, social, and personal competencies (Hecklau et al., 2017). When classifying competencies, they are most often distinguished (Jonek-Kowalska and Wodarski, 2018) as:

- technical, related to the use and handling of physical assets, techniques or technologies;

- organisational, aiming at skilfully planning own and teamwork using available organisational methods and techniques;

- conceptual, meaning the ability to plan and take actions of strategic character, oriented towards the development of the organisation and shaping its relations with environment;

- interpersonal, manifesting itself in the ability of interpersonal cooperation and social energy release.

In the literature on the subject we can often find the notion of key competencies referring to competencies needed by employers, that is, competencies that are missing on the labour market. Key competencies are understood as 'a combination of knowledge, skills and attitudes appropriate to the situation. Key competencies are those which all individuals need for personal fulfilment and development, active citizenship, social inclusion and employment' (2006/962/WE). The notion of future competencies is associated with foreseeable directions of civilisation changes concerning various spheres of life not limited only to the area of professional work (Kwiatkowski, 2018).

Methodology and research methods. The empirical research carried out on the assessed and identified key competencies of the future students was of a qualitative nature based on the interview method and the expert panel method. The research process preceded by literature analysis included a stage of discussion during the panel «The role of academic education in shaping future competencies» organised within the framework of the 7th WEZUT Conference - Forum of Deans of Faculties of Economics and Management of Technical and Military Universities in April 2019 and filling in a questionnaire. The research was conducted using a partially structured interview questionnaire, in which most of the variables were assessed using a 5-point Likert scale (where 1 was the lowest and 5 the highest). The research was based primarily on the method of managerial perception, which is one of the most practical and easy to use methods ensuring precise assessment of the examined conditions. For the purpose of the study, to assess the level of students' competencies and market demand for these competencies, classifications of competencies most frequently distinguished in the literature were adopted, divided into technical, organisational, conceptual and interpersonal competencies (Jonek- 
K. Wodarski, J. Machnik-Slomka, Semrau, J. Students' Competencies for the Future and Innovativeness - Research Among Managerial Staff of Public Universities of Technology in Poland

Kowalska and Wodarski, 2018). Based on the analysis of literature on the subject related to the issues of key competencies of students in the labour market, the following assumptions were made:

- there is a discrepancy in the assessment of technical university managers between the level of competencies held by students and the market demand for these competencies;

- soft competencies such as analytical skills, critical thinking, creativity, communication and teamwork will play a significant role among the key competencies of the future.

The respondents to the survey were the deans and pro-deans of the faculties of Polish public technical universities, where the courses of study in the field of social sciences within the disciplines of economy and finance as well as management and quality sciences are conducted. The research sample was selected on the basis of two criteria: membership in public technical universities in Poland emerging as a member of the KRPUT and fulfilling the function of a dean or vice dean for studies in the field of social sciences. The number of the research sample consisted of 31 deans and pro-deans representing faculties in the field of social sciences from 14 Polish public technical universities associated in KRPUT. KRPUT is a voluntary association of rectors representing Polish technical universities. A higher education institution shall be included in a group of technical higher education institutions on the basis of its authority to confer the academic degree of doctor in the field of technical sciences on at least one faculty or equivalent powers. The KRPUT is composed of 22 members of universities. Due to the fact that the research concerned the institutional market in the selection of the sample for research, the Pareto principle was adopted (Hague P. et al., 2014). Therefore, the size of the test sample with regard to the general sample is statistically representative.

Results. This chapter presents the results of empirical research conducted with the use of an interview questionnaire which was divided into the following four areas:

- assessment of the level of competence of graduates;

- evaluation of the level of demand on the labour market for particular competencies of university graduates;

- identification of future competencies;

- evaluation of the usefulness of teaching methods for shaping future competencies.

In the survey, a 5-degree Likert scale was used for most of the questions, giving the possibility to determine the degree of assessment. The grades were graded from 1-5, where 1 was the lowest and 5 the highest. The percentage of answers in relation to the studied area concerning the assessment of the level of competencies of university graduates is presented in Figure 1.

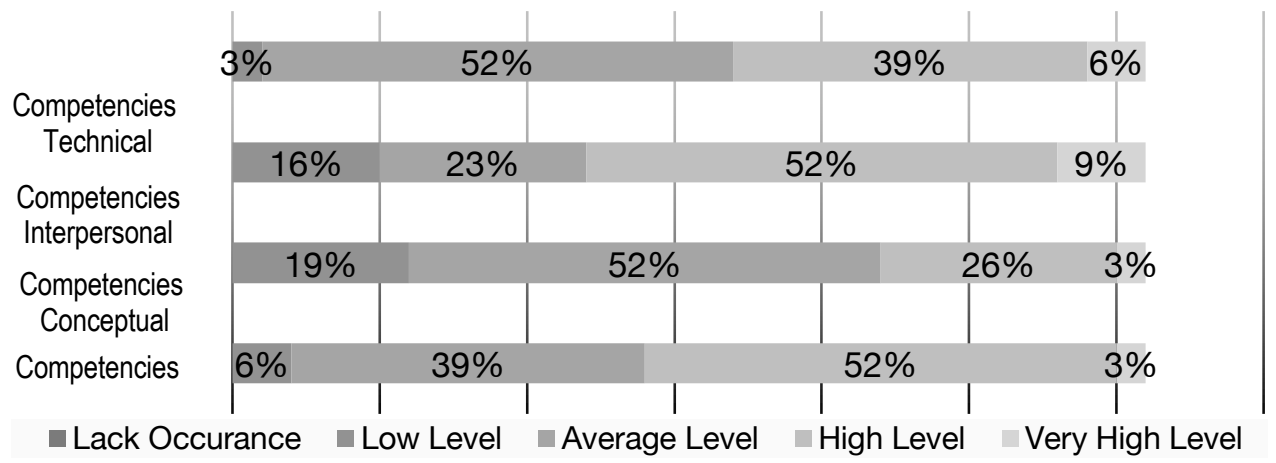

Figure 1. Assessment of the level of competence

Sources: developed by the authors. 
K. Wodarski, J. Machnik-Slomka, Semrau, J. Students' Competencies for the Future and Innovativeness - Research Among Managerial Staff of Public Universities of Technology in Poland

The analysis of the results presented in Figure 1 indicates that among the four competencies assessed at a high level, organisational competence (52\% of the answers) and interpersonal competence (52\% of the answers) were assessed. As far as the assessment of competence at the highest level is concerned, the percentage of answers obtained is small and amounts to $6 \%$ for technical competence, $9 \%$ for interpersonal competence, $9 \%$ for conceptual competence and $3 \%$ for organisational competence. Figure 2 presents the percentage of responses in relation to the assessment of the level of demand on the labour market for particular competencies of university graduates.

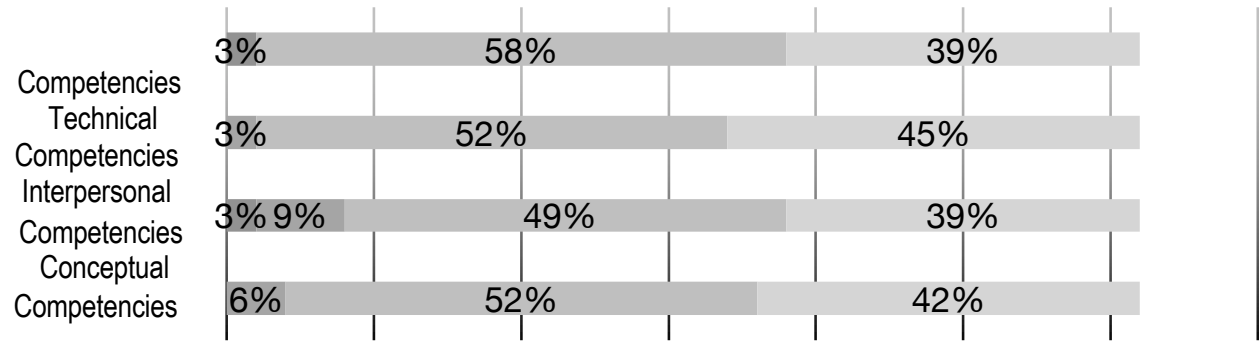

-Unnecessary $\quad$ Not Important $\quad$ Rather Important $\quad$ Important $\quad$ Very Important

Figure 2. Assessment of the level of demand on the labour market

Sources: developed by the authors.

The data presented in Figure 2 show that the respondents assessed the labour market demand for all four types of competencies very high. The highest percentage of responses was given to interpersonal competencies ( $45 \%$ of responses) and organisational competencies ( $42 \%$ of responses). Table 1 presents a list of the most frequently indicated competencies of the future by the management staff of the surveyed technical universities.

Table 1. Identification of competencies of the future

\begin{tabular}{|c|c|c|c|}
\hline Position & Competencies of the future & Position & Competencies of the future \\
\hline $\mathbf{1 .}$ & Creative Thinking & $\mathbf{6 .}$ & Interdisciplinary \\
\hline $\mathbf{2 .}$ & Teamwork & $\mathbf{7 .}$ & Multiculturalism \\
\hline $\mathbf{3 .}$ & Innovativeness & $\mathbf{8 .}$ & Conceptual Thinking \\
\hline $\mathbf{4 .}$ & Technical Competences & $\mathbf{9 .}$ & Knowledge of foreign languages \\
\hline $\mathbf{5 .}$ & Digital Competences & $\mathbf{1 0 .}$ & Interpersonal Competences \\
\hline
\end{tabular}

Sources: developed by the authors.

The research indicates ten competencies of the future which according to respondents may prove to be key in the labour market in the coming years. It is worth noting that among the 10 most frequently mentioned competencies of the future, the first three places were occupied by competencies such as Creative Thinking, Teamwork, Innovativeness. Figure 3 presents the percentage of responses relating to the assessment of the usefulness of methods of conducting classes for shaping future competencies. 
K. Wodarski, J. Machnik-Slomka, Semrau, J. Students' Competencies for the Future and Innovativeness - Research Among Managerial Staff of Public Universities of Technology in Poland

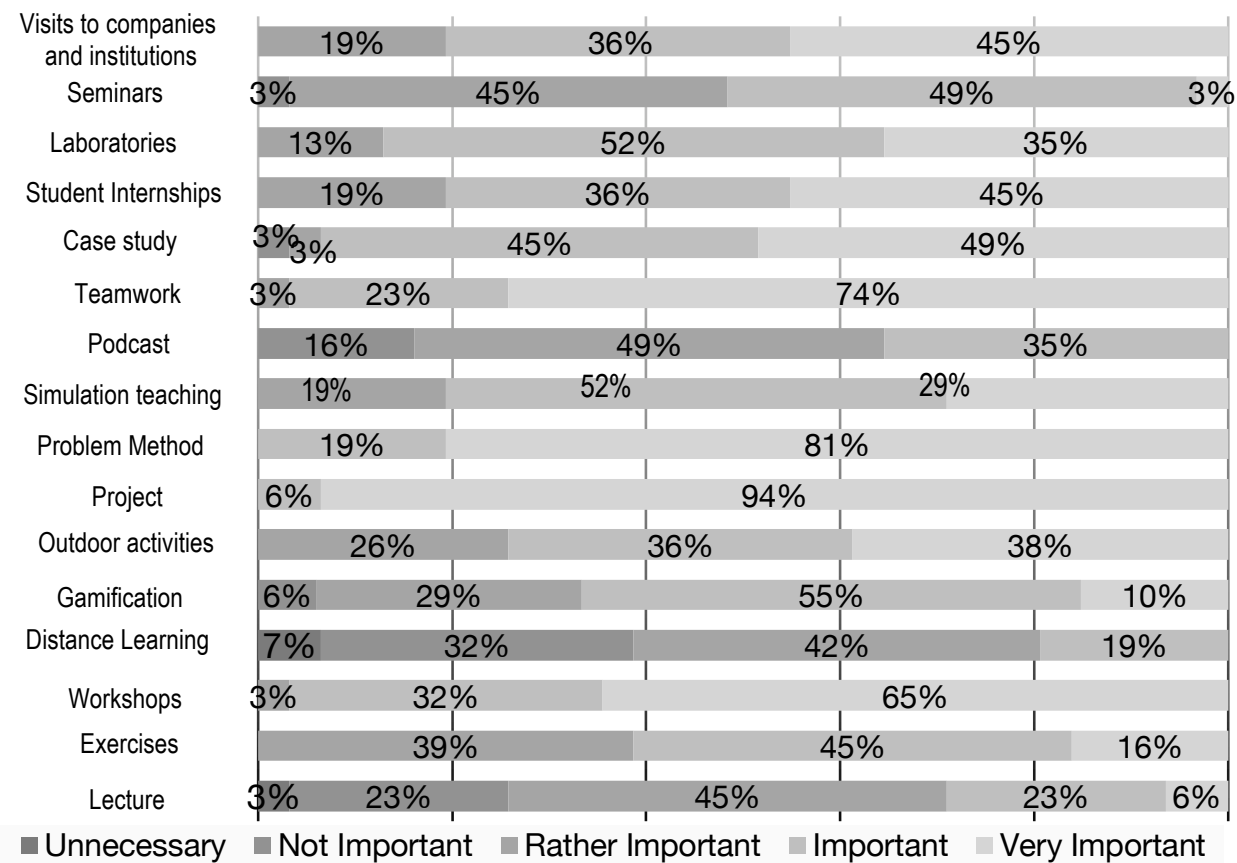

Figure 3. Assessment of the usefulness of the methods of conducting classes

Sources: developed by the authors.

As Figure 3 shows, the most significant methods of conducting classes for shaping future competencies were: teaching by projects ( $94 \%$ of answers), problem-based learning ( $81 \%$ of answers), teamwork methods ( $74 \%$ of answers), workshops ( $65 \%$ of answers) and case study methods ( $49 \%$ of answers). The lowest response rate for very important methods was achieved by the methods such as seminars (3\% of responses) and lectures ( $6 \%$ of responses).

Conclusions. Universities play a key role in the development of students' key competencies. This is why it is important to know about the changing needs of the labour market and the need to choose appropriate methods used in the teaching process. The presented research results prove the correctness of the assumptions concerning the discrepancies between the assessed level of students' competencies and the needs of the labour market and the directions of future competence development. Based on the literature analysis carried out and the results obtained from the empirical research, several general conclusions and recommendations can be defined in the context of shaping future competencies in order to increase the chances of university graduates in the labour market:

1. Due to the competencies of the future, indicated by the management staff of the surveyed universities, related primarily to creative thinking, teamwork, conceptual thinking, interpersonal competencies, there is a great need to introduce the so-called «soft» competencies into curriculums. Competencies relating to innovation, technical and digital competencies, interdisciplinarity, the ability to integrate different areas of knowledge and experiences, multiculturalism and language skills were also considered particularly important.

2. Representatives of the surveyed universities assessed that academic education for the development of competencies of the future should to a greater extent take into account the practical aspects of the fields of study. Therefore, it is necessary to use active forms of teaching, increase the 
number of practical classes, that is, teaching through projects, problem-based learning, methods of teamwork, workshops, case study methods.

3. Systemic support at the level of universities, creating an ecosystem based on cooperation with other partners, for example, in the field of exchange of knowledge and experience, conducting forecasting studies, is also vital for the effective development of competencies of the future of students.

To sum up, it is essential to develop knowledge, skills and attitudes related primarily to cognitive, social, interpersonal and also innovative competencies in order to develop competencies for the future of graduates on the labour market. Technical and digital competencies as well as those related to interdisciplinarity and multiculturalism, are also substantial. These results confirm the assumed assumption about the importance of innovative competencies among the competencies for the future identified by the respondents. These competencies ranked third in the most frequently indicated competencies for the future indicated by the respondents. These competencies can be seen as factors conditioning students' preparation for effective participation in social and professional life in the labour market and taking on different roles. In the above context, the need arises to shape a basic long-term competence related to the ability to react flexibly to new conditions, readiness for changes and active participation in their creation. The presented considerations and conducted research enrich the existing knowledge on the role and approach of universities to the fields of study and the competencies of students expected by the labour market. They do not, however, exhaust the complexity of the discussed issues. They are thereby the starting point for further in-depth research in this field.

Author Contributions: conceptualisation, K.W. and J.MS.; methodology, K. W. and J.MS; software, J. S.; validation, K.W., and J. MS.; formal analysis, K.W. and J. MS.; investigation, K. W., J.MS., J.S.; resources, K.W., J. MS., J. S.; data curation, J.MS. and J. S.; writing-original draft preparation, K.W., J. MS.; writing-review and editing, K.W., J. MS.; visualisation, J. S.; supervision, K. W.; project administration, K. W.

Funding: «This research received no external funding»

\section{References}

Boyatzis, R.E. (1982). The Competent Manager A Model for Effective Performance. John Wiley and Sons, Inc., New York.

Borowiec-Gabrys, M., Kilar, W., Rachwal, T. (2018). Przedsiebiorczosc jako kompetencja przyszlosci, [in:] Kwiatkowski, S.A. (ed.), Kompetencje przyszlosci, Wydawnictwo FRSE, Warszawa.

Ellstrom, P. E.., Kock, H. (2009). Competence development in the workplace: concepts, strategies and effects. In Illeris, K. (Ed.), International Perspectives on Competence Development. Developing Skills and Capabilities. London: Routledge.

Hecklau, F. Orth, R., Kidschun, F., Kohl, H. (2017). Human resources management: Meta-study-analysis of future competences in Industry 4.0. In Proceedings of the 13th European Conference on Management, Leadership and Governance: ECMLG 2017, Utrecht, The Netherlands, 18-19 October 2017; Academic Conferences and Publishing Limited: Utrecht, The Netherlands; $p .163$

Jerman, A., Peji'c, M., Bach, A., Bertoncelj, A., (2018). A Bibliometric and Topic Analysis on Future Competences at Smart Factories, Machines, 6, 41.

Jonek-Kowalska, I., Wodarski, K., (2018). Rola edukacji akademickiej w ksztaltowaniu kompetencji przyszlosci w kontekscie wydatków na szkolnictwo wyzsze w Polsce, Zeszyty Naukowe Politechniki Sląskiej «Organizacja i Zarządzanie», z. 124, Gliwice, pp. 33-42.

Kuzior A., (2014). Development of competences key to sustainable development, Zeszyty Naukowe Politechniki Sląskiej «Organizacja i Zarządzanie», z. 75, Gliwice.

Kwiatkowski, S.M. (red.), (2018). Kompetencje przyszlosci, Wydawnictwo FRSE, Warszawa

Markowski, A., Pawelec, R. (2003). Slownik wyrazów obcych i trudnych. Wydawnictwo Wilga, Warszawa, p. 451.

Mulder, M., Gulikers, J., Biemans, H., Wesselink, R., (2009). The new competence concept in higher education: Error or enrichment? J. Eur. Ind. Train., 33, pp. 755-770.

Najder-Stefaniak, K. (2010). Wartosc spotkania, Warszawa: Zaklad Filozofii WNH SGGW.

Hague P., Hague N., Morgan C. (2014). Badania marketingowe w praktyce, Onepress, pp. 90-91. 
K. Wodarski, J. Machnik-Slomka, Semrau, J. Students' Competencies for the Future and Innovativeness - Research Among Managerial Staff of Public Universities of Technology in Poland

Roberts, G., (1997). Recruitment and Selection: A Competency Approach; Chartered Institute of Personnel and Development: London, UK.

Spencer, L.M., Spencer, S.M., (1993). Competence at Work: Models for Superior Performance; Wiley: New York, NY, USA.

Stachowicz-Stanusch, A., Aleksander, A., (2018). Kompetencje przyszlosci, Zeszyty Naukowe Politechniki Slaskiej «Organizacja i zarządzanie», z. 121, Gliwice.

Zalecenie Parlamentu Europejskiego i Rady z dnia 18 grudnia 2006 r. w sprawie kompetencji kluczowych w procesie uczenia sie przez cale zycie (2006/962/WE).

Криштоф Водарскі, D.Sc.., Сілезький технологічний університет (Польща);

Йоанна Мхнік-Сломка, Ph.D., Сілезький технологічний університет (Польща);

Якуб Семрау, Сілезький технологічний університет (Польща). Польщі

Компетенції студентів для майбутньої інноваційності: дослідження менеджменту закладів вищої освіти у

Соціально-економічні процеси, розвиток технологій та супутні зміни створюють динамічне середовище, що вимагає інноваційних знань. У свою чергу, це провокує відповідні зміни на ринку праці, розширення знань та цілеспрямований розвиток компетенцій молоді. Таким чином, академічна освіта відіграє суттєву роль у даному напряму. У статті авторами розглянуто особливості формування ключових компетенцій студентів технічних спеціальностей університетів Польщі з точки зору академічної освіти з урахуванням основних особливостей інноваційного розвитку. Мета даної статті полягає у визначенні: ключових компетенцій студентів, які в найближчі роки будуть значимими, ефективних методів освіти, які сприяють розвитку та зміцненню компетенції враховуючі специфіку інноваційної діяльності. У свою чергу, емпіричне дослідження проведено з використанням методів інтерв'ю та експертної оцінки. При цьому респондентами дослідження стали декани фракультетів польських державних технічних університетів та їх заступники за такими спеціальностями як: економіка, фрінанси та управління. у статті представлено результати емпіричних досліджень, які обгрунтовують наявні розбіжності між набутими студентами компетенціями та їх попитом на ринку праці. Авторами зроблено припущення про те, що інноваційні компетенції відіграють важливу роль серед компетенцій майбутнього, визначених респондентами. Крім того, отримані результати дослідження свідчать про те, що розвиток знань, умінь і навичок, пов'язаних у першу чергу із когнітивними, соціальними та міжособистісними компетенціями, а також технічними, цифровими та інноваційними компетенціями, міждисциплінарним та мультикультурним розвитком, $\epsilon$ обов'язковими для випускників з метою забезпечення їх конкурентоздатності на ринку праці. Авторами зазначено, що результати дослідження можуть бути використані при фоормуванні та побудові навчального процесу, спрямованого на формування компетенцій студентів, затребуваних на ринку праці.

Ключові слова: компетенції, інноваційність, інноваційний менеджмент, освіта, ринок праці.

Manuscript received: 11.04.2019.

(C) The author(s) 2019. This article is published with open access at Sumy State University. 